\title{
Music Scoring Training in the Pare String Ensemble Music Community in Kediri - East Java
}

\author{
Raden Roro Maha Kalyana Mitta Anggoro ${ }^{1, *}$ Harpang Yudha Karyawanto ${ }^{1}$ Heri \\ Murbiyantoro $^{1}$ Autar Abdillah ${ }^{1}$ Noordiana $^{1}$
}

\author{
${ }^{I}$ Sendratasik Department, Faculty of Language and Arts Universitas Negeri Surabaya, Surabaya, Indonesia \\ *Corresponding author. Email: radenanggoro@unesa.ac.id
}

\begin{abstract}
Sendratasik Department, Language and Art Faculty, Universitas Negeri Surabaya, to carry out the Tri Dharma of University and efforts to grow with the character, it will carry out various activities that are manifested in the form of "Music Scoring Training in the Pare String Ensemble Music Community in Kediri". This training aims to introduce and implement digital literacy in the field of Music, namely about music scoring using the Sibelius software. This Sibelius software is later expected to be the main provision for each member of the Pare String Ensemble to develop the expected repertoire, increase professionalism in work (especially in operating the Music Learning Management System), and can become a superior selling power in the local, regional, even nationally. The activity of training the operation of the Sibelius software to the Pare String Ensemble community in Kediri, East Java, clearly showed significant results, where the soft skills of members in optimizing music technology devices were facilitated, which directly increased their productivity in carrying out musical activities, starting from arranging songs, to creating new musical works. With the increase in the skills of these members, it is also an investment for the Pare String Ensemble community institutionally, where the community has competitive offers or high selling power to music services users. In the end, the goal of the Pare String Ensemble community, Kediri - East Java to develop the existence and performance of their community, was achieved.
\end{abstract}

Keywords: Music Scoring, training, musician, ensemble

\section{INTRODUCTION}

Music is the abstract art form for people to express their inner thoughts, and it also is the art to express feelings and imbue emotion, which is created and promoted by humans and consisted of organized musical [1]. There are many ways to perform music works, for example: in a duet format, trio, band format, and the biggest format is an orchestra [2]. Orchestral music has always identified a performance for the nobility. It is rare for the lower middle class to enjoy orchestral music [3], [4]. Along with the development of music in Indonesia, especially in various cities and regencies in East Java, many reliable musicians have emerged from various universities both from abroad and domestically who have established music communities in the Kediri area. This causes public interest from various circles to be interested in joining the community. Music volunteers also joined in to advance the people who love music and who are competent in the realm of musical instruments [5]. Some pay a high price, some only pay as much as they can if they want to become a member in the community. Of course, the available funds will affect the existing facilities in each of these activities. It takes the help of volunteers to realize the visions and missions of this community.

Pare String Ensemble is a music group community that is engaged in orchestral music, especially string ensembles. This community has members from various circles; from academics and non-academics. The members of this community are young and seem enthusiastic. These youths are committed to build a pop orchestral music community, even though some of them 
do not have any basic skills in music. This group is led by Itot Brian Raharjo, S.Pd., MM, who also serves as the prayer coordinator.

Since 2017, Pare String Ensemble Music Community has had quite a lot of members. This community has been running for approximately 4 years, where the membership consists of young people, namely students and students, both male and female. Many young women who join this community play instruments, either string or woodwind instruments. The uniqueness of this community is their interest in learning orchestral music even with minimal facilities. This is what intrigues the community service team to care about the existence of the Pare String Ensemble Music community and the existence of the music group itself.

The Pare String Ensemble Music community always holds rehearsals once a week with a volunteer music teacher at the member's place in turn. The training location is uncertain because it does not have an adequate studio. Therefore, the practice site can be moved around, but most often it is in the house of the group leader. Even though they were accompanied by modest music teacher volunteers, they seemed enthusiastic about practicing and showed high motivation. They try to explore playing techniques with their equipment. Some play violin, cello, viola, saxophone, trumpet, trombone, and others, all of which are members' private property. Since its establishment, this community has performed incidental performances that are to donate in order to enliven social events or staging activities in schools, as well as others. (Based on the results of an interview with Rengga, S.Pd.).

The results of preliminary observations on the existence of the Pare String Ensemble Music community can be concluded that, by looking at the togetherness spirit of the members of this community, it is very possible to be pushed towards a professional who is money-oriented, or towards the creative economy, or creative industry [6]. On that basis, the Music Community Service Team of Language and Arts Faculty, Universitas Negeri Surabaya was tapped to provide guidance and empowerment to the music community of the Pare String Ensemble Music Community, namely through training in operating the Music Learning Management System in the form of software called "Sibelius". One unique thing about this community is that the majority of its members consist of young people, and many are even women, which is a selling point that is considered very attractive to gain market share in the entertainment world. In addition, the main thing to do in this training is how the Community Service team seeks to optimize the ability of individual community members to use the Sibelius software skillfully because it cannot be denied that parties who are committed to the realm of Music must also have literacy skills. qualified digital, as one of the competitiveness in today's entertainment world market. For more, technology is growing rapidly, making it very easy for musicians to carry out the training process. The application of technology and information is something that must be done in the world of music education and the music process because technology has become the main support for every activity, that is closely related to the millennial era [7].

In addition to optimizing the operation of the Sibelius software as one of the music scoring media, the community service team' activity that will be carried out in the Pare String Ensemble Music community also aims to improve skills in creating compositions, skills in making orchestral pop song arrangements, and skills in playing orchestral music. Trilling and Fadel in Mona and Hidayat [8] explained that $21^{\text {st }}$-century learning and training processes are oriented towards a digital lifestyle, thinking tools, learning research, and how knowledge works. All forms of skills in the $21^{\text {st }}$ century and Industrial Era 4.0 must be integrated into the educational element. The application of technology in the learning process provides significant changes and provides solutions to obstacles in the learning process; which also happens in the Pare String Ensemble Community. The results of the training itself are expected to encourage the creation of a creative industry for the music community of the Pare String Ensemble Music Community, especially in the pop music genre, can give birth to new forms and styles of pop orchestral music that are more popular in the community, especially those that are acceptable to young people, and can compete to fulfill market in the modern music entertainment industry.

There are various types of entertainment music in society, especially in East Java, from dangdut music to orchestral category music, which is no stranger to society. Entertainment, especially music, is an important component of an event. Every time there is an event, it must be equipped with musical entertainment as a supporter to enliven an event. Especially in the Kediri area and its surroundings, there are still very few entertainment service providers compared to market demand. The Pare String Ensemble Community is the only group engaged in the string orchestra genre. Seeing the stretching of all members of this group makes this community always eager to move forward in music. This is evidenced by the development in terms of training and the increasing number of members in a relatively short period. However, there are problems in this community from the team's observations, namely: (1) Lack of knowledge and skills in operating the Music Scoring Application (Software Sibelius), (2) Lack of detailed skills in terms of skills to play orchestral formation music, (3) Facilities which is not sufficient to develop this group, (4) Management of the group that is 
still not well-organized to enter the entertainment industry.

Seeing these conditions, the Community Service team wants to provide special training in the field of Music Scoring and the development of skills or skills to play stringed instruments to build this group so that it can become a professional and productive community in the entertainment industry.

In general, the purpose of this Community Service activity is to provide music scoring training in the form of software or Sibelius software to the Pare String Ensemble Music community. When the training activity ends, it is hoped that the participants will have the ability and skills to operate the Sibelius software, thus, each individual can develop the repertoire being trained. The importance of the study of these performing marks is that these symbols not only can fully show musical ideas but also provide recognition of the composer's performance mode [9]. The main goal point, the Pare String Ensemble community can have a high selling point towards the professional entertainment industry. Through the professionalism of music, it can also have a positive impact in creating industrial music that is in demand by the market, as well as providing solutions that have an economic impact for music practitioners, especially those who are members of the Pare String Ensemble Music community. In the end, it can be revealed that the excavated Sibelius that was used in the training process, can provide the latest developments and efficient publication media to musicians worldwide [10].

Specifically, this Community Service activity is to provide solutions to partners:

1. Optimizing the ability to operate the Music Scoring Application in the form of Sibelius Software, whose scoring output is following market needs.

2. As an effort to increase creativity and mastery of musical interpretation techniques of pop orchestral songs for the training participants of the Pare String Ensemble Music Group.

3. Find the forms and types of pop songs that participants are interested in and can be introduced as orchestral training materials in the Pare String Ensemble Music community.

4. Management of the group community towards the entertainment industry, to improve the economy.

5. Identify the responses of the participants to the Orchestra music training activities, as a basis for evaluation which will then be used as a basis for further development and coaching.

6. This Community Service activity is a form of service that applies knowledge about the realm of music, especially Music Scoring (Software
Sibelius) which is owned by the Community Service Implementation Team in collaboration with partners, namely the Pare String Ensemble Music Group Community. The participants who are the target of the training are those who have motivation and interest in improving digital literacy skills in the field of Music. The output that will be produced after this activity takes place is an increase in the mastery and skills of the participants in the creation of modern pop orchestral music using Sibelius software. The output that will be produced is in the form of software products that can be used independently by each community in developing each material or repertoire to be offered to the entertainment industry market. As a long-term target, the goals and results of this activity are expected to create a modern orchestra group that is reliable and based on the Creative Industry.

It is necessary to design a systematic and effective problem-solving framework. The problem-solving framework in question is as follows:

1. Preliminary study or identification of the target audience, namely to record the things needed by the training participants related to the implementation of music scoring training.

2. Preparation of materials, namely after identifying the condition of the target audience, then preparing training materials. This is done to coordinate the distribution of tasks for each member of the Community Service Team, to observe directly when the community is conducting training activities, and to hold discussions with the community coordinator. All of this is done to get the suitability of the material to be prepared, with the hope that the material to be applied can be accepted and useful for the target audience.

3. Determination of the schedule and place for the implementation of Community Service activities, namely discussing the exact schedule between the two parties. In this case, what is meant is not interfering with the activities between the implementer and the target audience. From the results of discussions with the Community Coordinator of the Pare String Ensemble Music Community, it was agreed that the activities were planned to be carried out from March-October 2021. The activities were carried out according to the agreed schedule, namely every Friday and/or Saturday afternoon, from 15.00-17.00. The materials that will be delivered in the activity according to the problem formulation are as follows.

a. Provide material on understanding music scoring using Sibelius software. 
b. Provide material on skills (direct practice) in operating the Sibelius software.

c. Guiding the community to start organizing the Pare String Ensemble Community towards a productive and professional community.

d. Helping trainees in creating or composing a new style pop song concept based on the creative industry.

e. Guiding entertainment management according to market needs.

\section{METHODS}

The relevant training methods to achieve this activity are (1) Presentation Method (Lecturing Session), (2) Demonstration Method, and (3) Simulation method. The various methods are as follows.

1. Presentation, in the form of presenting material explanations to participants regarding music scoring and song development/arrangement, as well as instrument-playing techniques. In addition, it provides insight on how to manage this group towards a productive entertainment industry market.

2. Demonstration, namely at this stage, the Community Service Team provides examples of the operation of the Sibelius software, techniques for playing instruments (String ensembles), both individually and in integrated groups.

3. Exercise/Simulation, where participants try to do exercises in compiling the composition/arrangement of pop songs:

a. Beginning with the preparation of the concept of composition and or arrangement of modern pop songs.

b. Practice playing each independent instrument, ensemble, and conducting technique.

During the implementation of the activity, the training participants as partners will participate as active participants in absorbing the knowledge of music scoring, as well as the art of orchestral music provided by the Community Service team.

\section{RESULT AND DISCUSSION}

Sibelius is a product of Avid Technology that has been featured with a facility to play VST based musical instruments [11]. In line with that, Sibelius is professional notation software that allows the creation and complete editing of a whole music score or its parts with audio playback options. The software offers use of various styles of musical notation, including a special notation with additional modules (plugins) Audio-Score and Photo-Score which can even create the sheet music directly form singing or musical playing through a microphone or ready-made audio recording or can convert the printed or handwritten score to electronic musical forms with using a scanner. Now this software, which is continuously improving, is not only the perfect notation tool but also a versatile multimedia one [12]. This opinion was also emphasized, that Sibelius has complete features, is easy to use, and is compatible to be installed on various types of computer devices [13]; Sibelius is an application that can be used to perform all music writing activities, from writing music notation, making music, and playing it, so the Sibelius software is suitable for use in the training process for musicians.

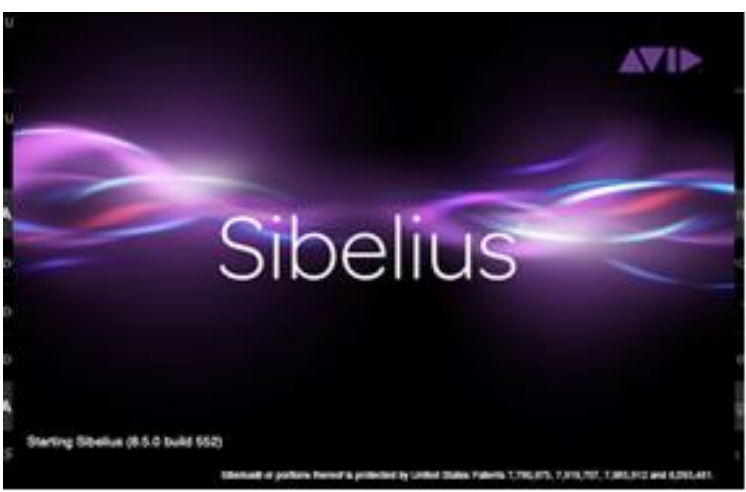

Figure 1. Sibelius Software first appearance (https://www.avid.com/sibelius, 2021)

Nowadays, Sibelius software is a strategic medium for musicians or music educators to compose and/or do some music production activities, including for the Pare String Ensemble Music Community. The Pare String Ensemble Music Community, which aspires to develop in its musical activities, not only wants to be consistent in practicing the skills of playing strings in chambers or orchestra formats but also wants to accelerate in terms of composing and also creating musical works. As we all know that musical works are one of the main materials for musicians, then the Pare String Ensemble Music Community also wants every member of its community to have soft skills in operating the Sibelius software so that in the end, it can facilitate each member to carry out music production activities. Community Service Activities carried out by the Sendratasik Department team, Faculty of Language and Arts, Universitas Negeri Surabaya strive to jointly realize the ideals of the Pare String Ensemble Music Community. Universitas Negeri Surabaya team held practical training activities for members of the Pare String Ensemble Music Community in operating the Sibelius Software. The training activity was carried out virtually (because it was still during the Covid 19 pandemic), done once a week, using video conferencing media. Overall, members of the Pare String Ensemble Music Community were enthusiastic about participating in the training activity. However, not a few obstacles were encountered, one of which was because community 
membership was heterogeneous, in the sense that not all had sufficient basic skills to operate technological devices so that in the process of delivering learning material, the Universitas Negeri Surabaya team often had to repeat several certain parts to members of the Pare String Ensemble Music Community. However, this did not dampen the enthusiasm of the members in participating in training activities.

After participating in a series of continuous and intense training activities, the members of the Pare String Ensemble Music Community were able to operate and perform song composing activities using the Sibelius software. Referring to the community format that they carry, the song compositions format is also adjusted to the format of their community, which is in the format of strings chambers and/or orchestra. The followings are the examples of a sample pop song that was arranged by a member of the Pare String Ensemble Music Community in some strings sections music score, after participating in a music scoring training activity that held by the Universitas Negeri Surabaya team:

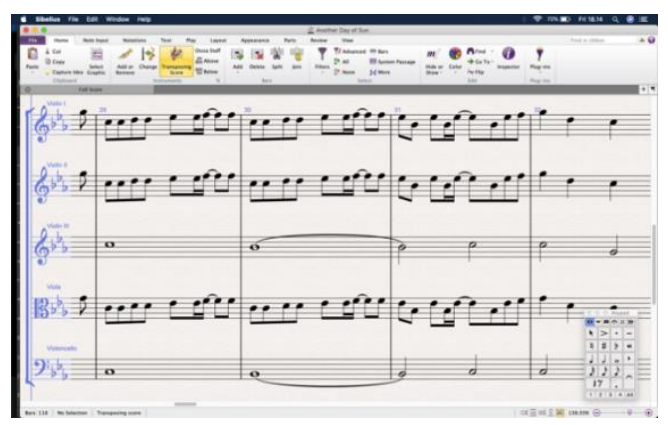

Figure 2. Full Music Score of "Another Day of Sun" (private documentation, 2021)

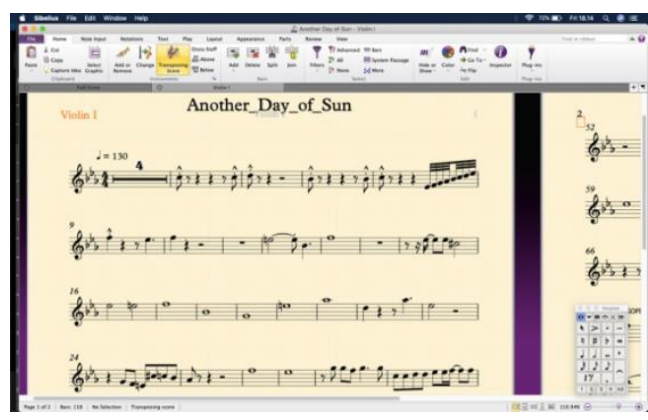

Figure 3. "Another Day of Sun" $1^{\text {st }}$ Violin Music Score (private documentation, 2021)

These soft skills certainly create new and more enthusiasm for members of the Pare String Ensemble Music Community. By being able to operate music software (namely Sibelius Software),

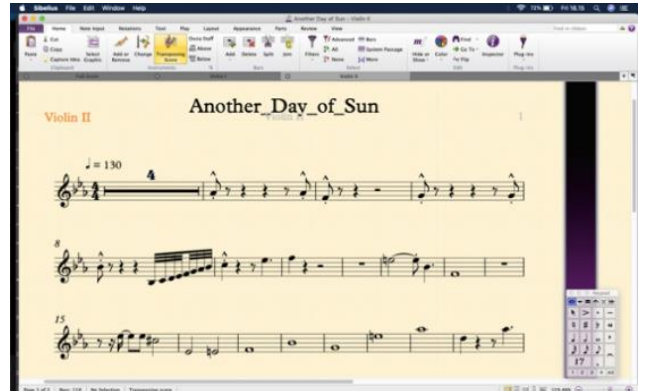

Figure 4. "Another Day of Sun" $2^{\text {nd }}$ Violin Music Score (private documentation, 2021)

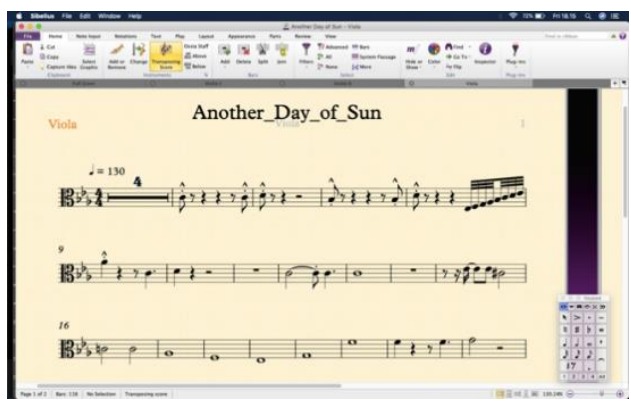

Figure 5. "Another Day of Sun" Viola Music Score (private documentation, 2021)

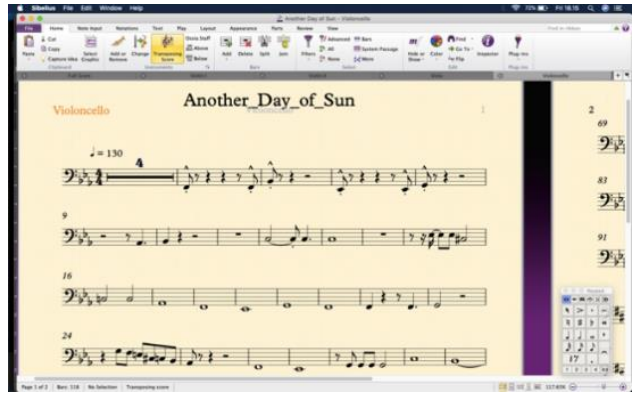

Figure 6. "Another Day of Sun" Violoncello Music Score (private documentation, 2021)

It opens opportunities for the community to produce musical works, which in the end, these musical works are not only a medium of existence for Pare String Ensemble music itself, but can also be used as a prospective business offer for service users in the neighborhood of the Pare String Ensemble Music Community, or for the wider community.

\section{CONCLUSION}

The activity of training the operation of the Sibelius software to the Pare String Ensemble Music Community in Kediri, East Java, clearly showed significant results, where the soft skills of members in optimizing music technology devices were facilitated, which directly increased their productivity in carrying out musical activities, starting from arranging songs, to creating new musical works. With the increase in the skills of these members, it is also an investment for the Pare String Ensemble Music Community institutionally, where the community has competitive offers or high selling power 
to music services users. In the end, the goal of the Pare String Ensemble Music Community, Kediri - East Java to develop the existence and performance of their community, was achieved.

\section{REFERENCES}

[1] Wang, J. (2015, April). Management Software Development for Online Music Audio-visual. In International Conference on Advances in Mechanical Engineering and Industrial Informatics. Atlantis Press.

[2] Peyser, Joan, ed. (1986). The Orchestra: Origins and Transformations. Charles Scribner's Sons. ISBN 0-684-18068-5.

[3] Raynor, Henry (1978). The Orchestra: a history. Scribner. ISBN 0-684-15535-4.

[4] Sptizer, John, and Neil Zaslaw (2004). The Birth of the Orchestra: History of an Institution, 16501815. Oxford University Press. ISBN 0-19816434-3

[5] Bastomi, Suwaji. 1990. Wawasan Seni. Semarang: IKIP Semarang Press.

[6] Tim Penulis, 2009. Potensi Ekonomi Kreatif. Surabaya: Dewan Kesenian Jawa Timur

[7] Sinaga, F. S. H. S., Maestro, E., Marzam, M., \& Yensharti, Y. (2019). Software Sibelius Sebagai Alternatif Penulisan Notasi Musik Di Era Millenial. Musikolastika: Jurnal Pertunjukan Dan Pendidikan Musik, 1(1), 1-6.

[8] Mona, D., \& Hidayat, H. A. (2021, March). Utilization Software Sibelius Basic Vocals in Department of Sendratasik Universitas Negeri Padang. In Ninth International Conference on Language and Arts (ICLA 2020) (pp. 354-358). Atlantis Press.

[9] Deng, K. (2018, July). Vocal Score and Piano Score The Interaction Between Chamber Music and Vocal Music of Chinese Composers. In 4th International Conference on Arts, Design and Contemporary Education (ICADCE 2018) (pp. 144-147). Atlantis Press.

[10] Hou, Y., Zhao, X., \& Guo, X. (2017, December). The Value of Antique Music Score in Li Bai Poem. In 4th International Conference on Education, Language, Art, and Intercultural Communication (ICELAIC 2017) (pp. 508-514). Atlantis Press.

[11] Julia, J., Supriyadi, T., \& Iswara, P. D. (2019, February). The development of angklung composition teaching materials using Music Notation Software with virtual studio technology integration. In Journal of Physics: Conference Series (Vol. 1157, No. 4, p. 042005). IOP Publishing.

[12] Sedláček, M. (2010). Music Software Used by Teachers in Music Education at Elementary Schools of Czech Republic. The Multimedia Technologies Applications in Music Education. Brno, 33-38.

[13] Saputra, D. N. (2020). Peningkatan Kompetensi Mahasiswa Dalam Komposisi Musik Melalui Penggunaan Software Sibelius. Jurnal Kajian Seni, 6(2), 142-162.

[14] A. Pnueli, In the transition from global to modular temporal reasoning about programs, in: K.R. Apt (Ed.), Logics and Models of Concurrent Systems, Springer, Berlin, Heidelberg, 1984, pp. 123-144. DOI: https://doi.org/10.1007/978-3-642-82453-1_5

[15] B. Meyer, Applying "Design by Contract", Computer 25(10) (1992) 40-51. DOI: https://doi.org/10.1109/2.161279

[16] S. Bensalem, M. Bogza, A. Legay, T.H. Nguyen, J. Sifakis, R. Yan, Incremental component-based construction and verification using invariants, in Proceedings of the Conference on Formal Methods in Computer-Aided Design (FMCAD), IEEE Press, Piscataway, NJ, 2010, pp. 257-256.

[17] H. Barringer, C.S. Pasareanu, D. Giannakopolou, Proof rules for automated compositional verification through learning, in Proc. of the 2nd International Workshop on Specification and Verification of Component-Based Systems, 2003.

[18] M.G. Bobaru, C.S. Pasareanu, D. Giannakopoulou, Automated assume-guarantee reasoning by abstraction refinement, in A. Gupta, S. Malik (Eds.), Proceedings of the Computer Aided Verification, Springer, Berlin, Heidelberg, 2008, pp. 135-148. DOI: https://doi.org/10.1007/978-3540-70545-1_14 